\title{
特集 Primary myocardial disease
}

\section{特発性心筋疾患の病理}

\author{
一一形態学的分類の理論的根拠一
}

岡田了 三*

\section{はじめに}

特発性心筋疾患に対しては Idiopathic myocardiopathy をはじめとして, 特発性心筋症 Idiopathic cardiomyopathy, 原発性心筋病 Primary myocardial disease, 特発性心拡大症 Idiopathic cardiomegaly, 特発性心肥大症 Idiopathic cardiac hypertrophy, 特発性心筋肥大症 Idiopathic myocardial hypertrophy, 特発性心筋線維症 Idiopathic myocardial fibrosis など多少の二ュ アンスのちがいをこめてさまざまな名称が与え られてきた1．これらを大ざっぱに多少の差は あっても同じものとして一縓めにあつから立 場2) は臨床的にはある程度止むを得ないにして も，その病因が単一でなく，まして従来診断の 明らかとなったものを除外して，な括のこる心 疾患としてクズカゴ的取扱いをらけてきた雑多 なものの総括名にすぎなかった群を理由なく症 候群または疾患名にまで昇格させて，いたずら に混乱を大きくする危険がある。

そこで著者は，剖検材料を用いて病理所見を 単純な要素にまで分解して, 高血圧, 既知の内 分泌代謝疾患, 冠状硬化症, 弁膜疾患をもたない 心筋の原因不明の病変が主役で心内膜 ・ 心外膜 病変はわずかであるか，明らかに 2 次的とみな されるものを特発性心筋疾患 Idiopathic myocardiopathy とょび，心臓と筋肉の疾患ともと れる紛らわしい Cardiomyopathy といら名称は 排除する立場を主張してきた ${ }^{334)}$.したがって 著者の立場からは原因不明の心疾患 Cardiac

* 順天堂大学医学部循環器内科 disease of unknown etiology が特発性心筋疾患 とその類緑疾患 Allied cardiac disease に 2 大 別されることになる。

この形態学的分類のよって立つ理論的根 拠5)6) を本論文で明らかにしたい.

\section{I. 特発性心筋疾患にみられる非特異的病変}

\section{1. 拡張と肥大}

歴史的にみると本疾患は, 特発性心肥大症の 名称で長く親しまれてきたことからわかるよう に，とにかく心蔵が大さく重くなることが特長 的であるて.

この心重量の増大は, 心内腔が拡張すると壁 内張力が増大 ${ }^{8)}$, 心筋細胞が代償的に肥大し て単位面積あたりの心筋が負担すべき，または 発生せねばならない張力を軽減する機序であり 心拡張の原因がなんであれ，ある限度をこえた 拡張であれば当然肥大は続発するべき現象であ ると考えられる。

この肥大と拡張の条件をできるだけ単純化し た心臓模型を用いてシミュレートしたものが図 1 である。左上（A）に正常心の拡張期左心室 として半径 $4 \mathrm{~cm}$, 厚さ $1 \mathrm{~cm}$ の半球を仮定する. 血圧は，正常值として $100 / 70 \mathrm{mmHg}$ を与える とこの左心壁内張力は Laplace の定理より次 の式で与えられる。

$$
T=\frac{k}{T h} \cdot \frac{P}{\left(\frac{2}{R}\right)}=\frac{k P R}{2 \cdot T h} \quad \begin{aligned}
& P: \text { 心室内压 } \\
& R: \text { 心室半径 } \\
& T h: \text { 心室壁厚 }
\end{aligned}
$$

この式に拡張期半径 $R_{d}$, 厚さ $T h_{d}$, 拡張期血 圧を代入すると等容収縮期の単位面積あたりの 壁内張力 $T_{i}=1.9 \times 10^{5} \mathrm{dyne} / \mathrm{cm}^{2}$ として求めら 
れる. 次にこの直径が収縮終期に $3 \mathrm{~cm}$ まで減少すると仮定すれ ば, その場合の左心室 1 回拍出量 は半球の体積減少から $74 \mathrm{~m} l$ とな り，ほぼ正常模型として使用しう る価を示している。そこで収縮期 半径 $R_{s}$, 収縮期壁厚 $T h_{s}$, 収縮期 血圧より求められた張力は, 注ぼ 駆出期の張力とみなされ $T_{e}=1.3$ $\times 10^{5} \mathrm{dyne} / \mathrm{cm}^{2}$ となる。 心筋の比 重をほぼ 1 とみなせば, この左心 室模型の重量は $120 \mathrm{~g}$ となり, 全 心重量の $2 / 3$ を左心室が占めると すれば, この心蔵模型の重量は $180 \mathrm{~g}$ と計算され, 正常心として 非常識な值ではない。

図の右上 ( B )は, 心筋に異状を 発生して左心室の拡張期半径が 2 倍の $8 \mathrm{~cm}$ まで拡大した場合であ る。心筋量に増加がなければ左心 室壁は引きのばされてらすくなり 正常の $1 / 3$ の $0.3 \mathrm{~cm}$ となってし まう．正常血圧と正常拍出量を維 持するためには等容収 縮 期 張力 $T_{i}=13 \times 10^{5}$ dyne $/ \mathrm{cm}^{2}$, 駆出期 張 力 $T_{e}=17 \times 10^{5} \mathrm{dyne} / \mathrm{cm}^{2}$ となり
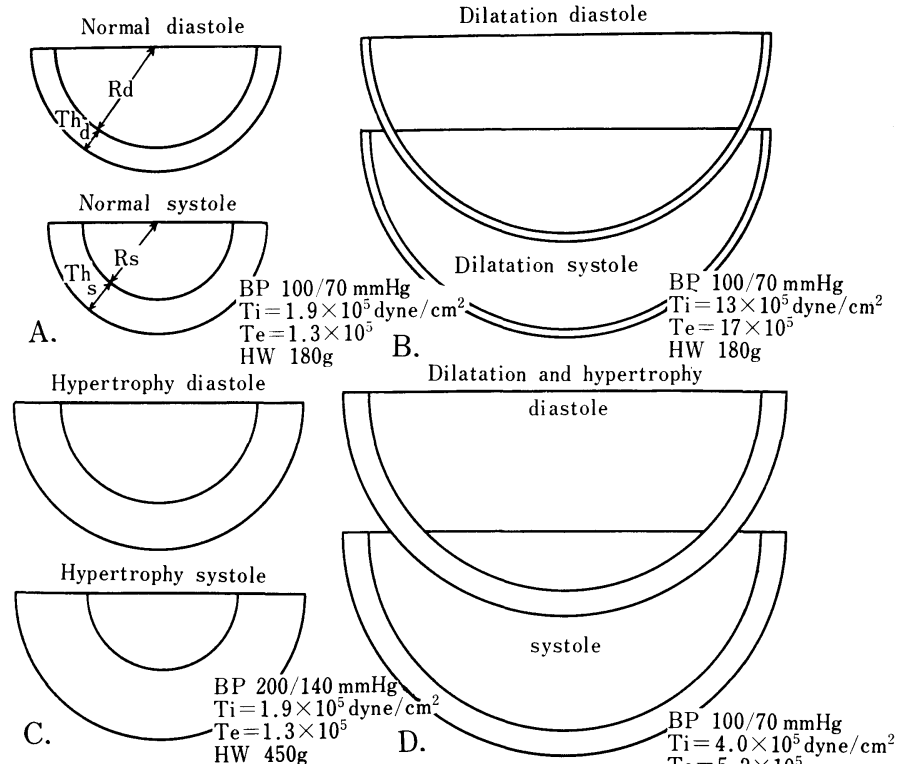
実に正常の10倍近い強力な張力の

発生が正常の心機能を維持する上に必要とな る。ちなみにこの場合の半球（左心室）の半径 は $74 \mathrm{~m} l$ の拍出量を維持するためにわずか 0.2 $\mathrm{cm}$ 縮少すれば事たりるわけで拡張・収縮期に ほとんど大きさはかわらないことになる。

さて, 内腔が半径 2 倍に拡大した場合左心室 が正常の厚さを保っている, 寸なわち拡張期に $1 \mathrm{~cm}$ の壁厚が維持されていると仮定した場合， 図 1 右中段（D）のようになる。正常の厚さを 維持するには心筋量は 3.6 倍に増加し心重量は $650 \mathrm{~g}$ となる必要があり, 肉眼的には単に拡張 がつよいといら印象しかなくても，実はつよい 肥大が合併しているわけである。この場合正常 血圧, 正常拍出量を 維持するためには等容収 縮期張力 $T_{i}=4.0 \times 10^{5} \mathrm{dyne} / \mathrm{cm}^{2}$, 駆出期 張力

$T_{e}=5.2 \times 10^{5} \mathrm{dyne} / \mathrm{cm}^{2}$ を必要とし, 正常の 2 〜 倍の増加となる。 この状態が，いわゆる拡 張性肥大, または遠心性肥大といわれている状 態である ${ }^{10)}$.

内腔の直径が 2 倍となった場合に, 壁厚も 2 倍となったと仮定すると図 1 下段（E）図のよ らに, 計算された心重量は実に $1,500 \mathrm{~g}$ といら 巨大なものとなる. 正常血圧・正常拍出量とし て等容収縮期張力 $T_{i}$ は正常心なみであるが, 駆出期張力 $T_{e}$ は, ほぼ正常の 2 倍である 2.5 $\times 10^{5} \mathrm{dyne} / \mathrm{cm}^{2}$ のはずである. 肉眼病理的には かかる心蔵は肥大の著るしい牛心といらことに なる。

内腔の拡張を伴わない壁厚だけ増加している 心臓は左中段（C）に示す求心性肥大である。 

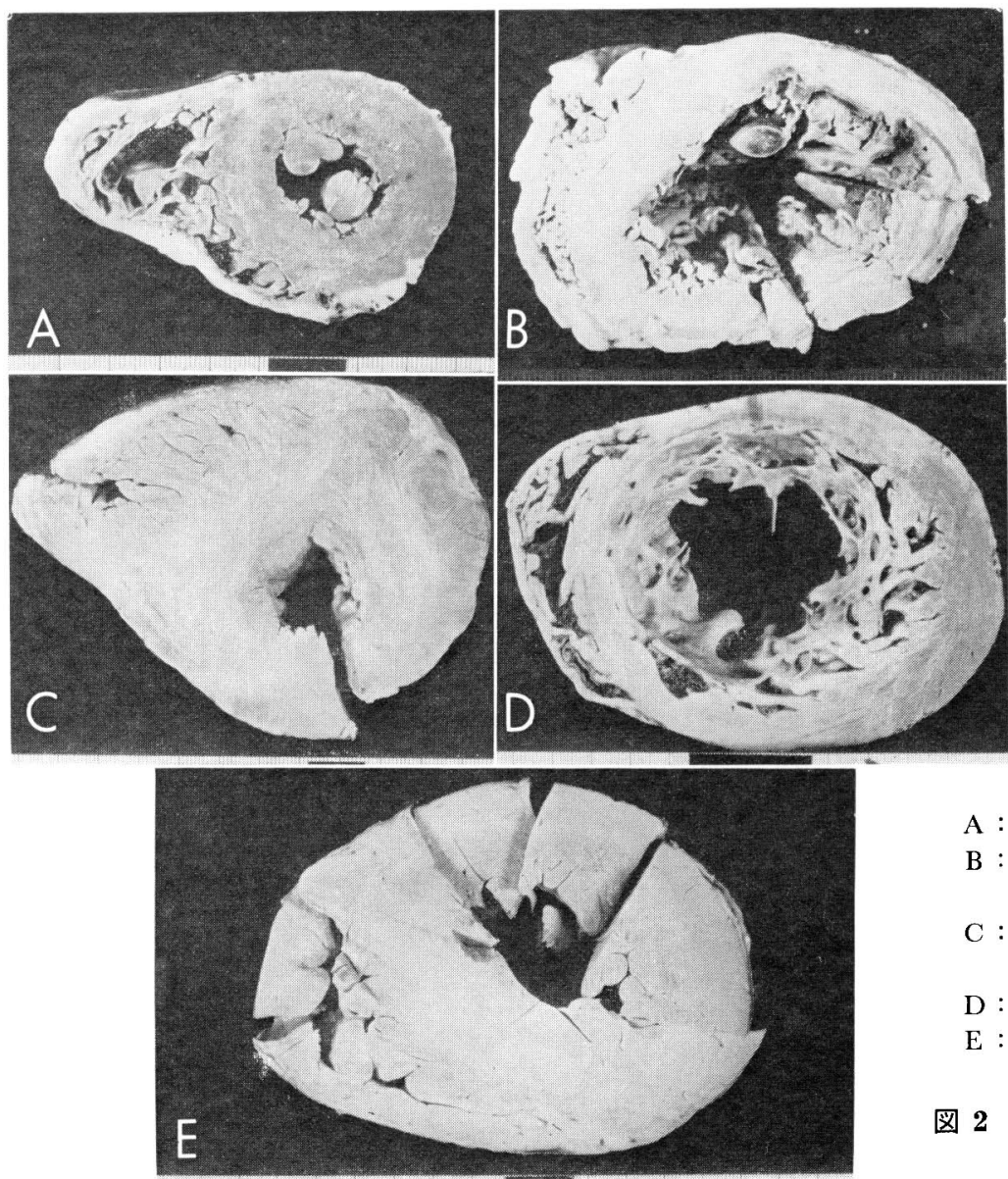

A：正常心 $210 \mathrm{~g}$

B：変性型特発性心筋疾患 360 g.

C：肥大性閉塞性心筋疾患 610 $\mathrm{g}$.

D：混合型特発性心肥大 $820 \mathrm{~g}$.

$\mathrm{E}$ ：心筋炎後心肥大(WPW 症 候群老伴5) $1190 \mathrm{~g}$.

図 2 特発性心筋疾患の肉眼所見

正常の 2 倍の $2 \mathrm{~cm}$ の壁厚とすれば心重量は $450 \mathrm{~g}$ ，壁内張力を正常と仮定すれば，その場 合は血压が 2 倍の $200 / 140 \mathrm{mmHg}$ となるはずで 压負荷型肥大ともよばれる高血圧の持続してい る心蔵ということになる。

このような拡張・肥大の組合せは特発性心笳 疾患にすべてみとめられる，剖検心は心筋の死 後硬直の関係もあって，ほほ济収縮期の大きさに

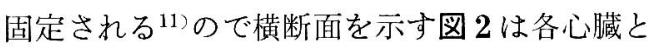
も，医济収縮期の形とみてよい．残念ながら 〜 E図の下側のスケールからみてもわかるよう に縮尺は全例同じではないのでD・E図は実物 よりも小さく示されている．各例とも下方が前 面でむかって右が左心室になるように並べてあ る.

さて図 2 A は正常心で，Bはわずかに心重量 の増加はあるが，左心室の搪張が主徵である特
発性心筋疾患である ${ }^{12}$. か上らに搪張のみがみ られる心筀疾患が存在するため従来の特発性心 肥大症といら名称が総括名として不適当となっ て改名の必要がでたわけである，C図は特発性 肥厚性大動脈弁下㹨窄症 (IHSS) と従来よばれ て和り, 肥大性閉塞性心筋疾患 (Hypertrophic obstructive myocardiopathy) とも称される特殊 な心筋疾患である。内腔の拡張はほとんどな く，心室中隔が特につよく肥厚しているのが特 長である ${ }^{13)}$ 。この例は左心室内圧 $160 / 0 \mathrm{mmHg}$ で流出路に $42 \mathrm{mmHg}$ の圧較差があるため動脈 圧は正常であった。したがって，このC図にみ られる求心性肥大は高血圧時にみられる圧負荷 に対する肥大と共通要素があり压負荷のない他 の特発性心筋疾患とは極立った相違があるた め, 原因不明とはいいながら, 著者は別格扱い として特発性心筋疾患の亜型として類緑疾患の 
範疇に入れることを提唱している，D図は典型 的な特発性心筋疾患で拡張性肥大が 高度であ る14)。 E 図は心外膜・心筋炎が先行した WPW 症候群を伴う高度の心肥大例 ${ }^{15)}$ で，心重量は $1,000 \mathrm{~g}$ をえる。

かように特発性心筋疾患は，一定の拡張・肥 大の組合せをもたず，拡張のみ目立つもの，拡 張と肥大のバランスがとれているもの，肥大性 閉塞性心筋疾患をのぞいてもなお肥大が拡張よ り目立つ例がすべて含まれて括り，拡張・肥大 はむしろ非特異的な属性とみなした方がよい。

\section{2. 心筋の変性・肥大と線維症}

光学顕微鏡による心筋組織像の検討を図 3 に 示す．Aに対照として提示した正常の左心室心 筋を参考として以下の組織像と比較願いたい.

$\mathrm{B} \cdot \mathrm{C}$ 図は拡張が目立ち，心重量増加はごく わずかである拡張を主とする心筋疾患である。

B 図例は分娩後心筋疾患で比較的急性経過をと

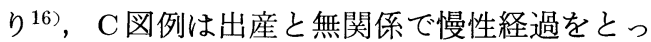
た ${ }^{12) 17)}$. 組織学的にはともに心筋細胞の肥大は なく，むしろ一部が細く萎縮し大小不同が目立 つ. B 図では限局性の心筋細胞の脱落と小血管 の拡張, 核の变形, 筋細胞原形質の軽度の染色 性変化がみられるが間質に全く炎症性細胞の出 現はみられない，C図では心筋細胞索は各所で 介在板部位（細胞間接合部）で離断し ${ }^{18)}$ ，部分 的に結合織が増加しているがやはり炎症所見は ない，かような所見の少なくとも一部は心室壁 のつよい引きのばされによる非特異的変化とい 学る。図 1 B ・ 2 B より予想される心筋内張力 の異常増加は弾性体とみなした平滑筋の Young 率をこえて，弾性線維のそれの60\%にまで達し

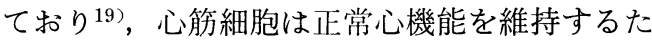
めには，常に引きのばされて心拡張は進行せざ るを得ない条件下にあるといえよう。一方，心 筋細胞の引きのばされは Starling の法則に従 えばより強い張力を発生することになるが，域 值をこえて過剩の引きのばされをらけると， Starling 曲線の下行脚へのって収縮力は低下す る可能性があり, 従来拡張心の心不全の説明に 用いられている，筋細胞の引きのばされを筋節 の長さで扣きかえてみると横紋筋の筋節は 2.0

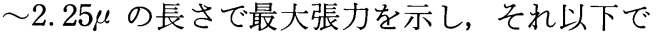
もそれ以上でも発生しうる力は減少し， $3.65 \mu$ まで引きのばされると張力は 0 になるといわれ ている ${ }^{20)}$. 生理的な筋節長 $1.8 \sim 2.2 \mu$ が 2 倍に 引きのばされることは, 張力発生 0 という心筋 収縮力の言失を意味しているので心筋の離断か 心筋構築の変化なしには図 1 B の程度までは拡 張し得ないことになる，心筋の収縮力をのこし てつよく拡張するには, 介在板の離開か, 所々 での心筋細胞の死隇部でゴム紐がきれるように 細胞索がきれる必要 ${ }^{21}$ があり, 一度拡張への引 き金が引かれてしまえば, 図 $3 \mathrm{~B} ・ \mathrm{C}$ のごとき病 変が非特異的に発展し，非可逆的病変となるこ とを示している．引きのばされの方向が心筋細 胞索と直角方向であれば，細胞索の排列が変っ て，拡がった細胞索間の吵間に相隣る層の細胞 索が入りこんで厚さの減少分だけ横に長さを増 すといら心筋構築の変化を伴う拡張 (Plastische Gefügedilatation) ${ }^{10)}$ も考えらる。【かし細胞索 間には側枝による連結があるので側枝が離断す ることによる心筋細胞障害が同時に発生するこ とになり，いずれにしても心筋細胞の負担増加 に対応する変性と過度の引きのばされによる部 分的細胞壊死とそれを置換する線維症, 細胞構 築の変化に伴ら血管周囲・細胞周囲間質の結合 織増加が 2 次的に発生する，かような変化が心 室壁全体に一様に発現すれば，冠状動脈分布の 末梢である左心室後壁・心尖部よりの部分と心 内膜下層は他の部分より $\mathrm{O}_{2}$ 供給がおくれるた めの不利益をもつので抵抗減弱部位としてもっ とも進行した病変をもつはずである. 図 $2 \mathrm{~B}$ の ごとくこの型の心筋疾患では，まさにその部位 に線維症をはじめとするもっとも進んだ病変が みられるので，逆に拡張によってつくられた悪 循環が 2 次的な心筋変性・脱落・線維症の進展を よぎなくさせて収縮機能低下を主とするらっ血 性心筋疾患 22 の病像を呈するのであろらと推論 できる.したがって，この型は心筋の変性が正面 にでるので組織学的には変性型特発性心筋疾患 とほぼ対応することになる。この型の症例は, しばしば左心室が正常の逆円錐または回転棈円 形から球状に拡張するので長軸方向よりも横径 
の拡大がつよい，その場合もっともつよい引き のばされは横走する中層輪状筋に発生すること となるので 2 次的病変は中層をつょくおか し23), 冠状循環上も力学的にももっとも有利と なるのは外層斜走筋のみといらことになるはず で，この法則にみあった病変分布をとる場合は 2 次的に抎張による促進をらけたと考光てよ い. したがって変性（純拡張）型心筋疾患の病 因は内腔拡大を生じさせる第 1 の要因と, 増加 した壁内張力の刺激で当然続発するべき心筋肥 大を妨げる第 2 の要因よりなることが推定され る.

図 $3 \mathrm{D}$ は内腔の拡張と肥大のバランスがとれ た図 $1 \mathrm{D} ・ 2 \mathrm{D}$ に相当する拡張性肥大を特長と する心筋疾患の左心室の組織像である. 多くの 心筋細胞は正常の 2 倍程度の直径をもち, 筋原 線維の増加と核の Pyknose が認められる.いま 心筋細胞の直径のみが 2 倍となり長さが不変で あると心重量増加は 4 倍, 直径長さとも 2 倍と なれば重量は 8 倍となり, 図 1 の正常心 $180 \mathrm{~g}$ を基準とすると，それぞれ720 g，1,440 g まで 増加することになる。この概算は心筋の肥大を 主として既在の心筋細胞が太くなることで達成 され，数の増加は無視してよいことを示してい る。この肥大心筋が大きさに比例して収縮力の 増加をもつかどらかは猶異論もあるが, 肥大が 拡張による壁内張力増加に誘発されて発生し, 全体として収縮力増加に寄与していることは間 違いない24125)。この肥大の引き金としては内圧 上昇と拡張による壁内張力増加の両方が考学ら れ，前者は閉塞性心筋疾患，後者は著者のいら 肥大型特発性心筋疾患に相当する. 閉塞性心筋 疾患は別項で扱うこととし, 拡張性肥大型につ いて検討すると, 肥大した心筋細胞は, たしか に単位面積あたりの担らべき張力を減少させる ので上述の純拡張群に比して, ひきのばされに よる障害は軽くなるはずであるが, 細胞体積の 増加は心筋構築のワクをつくる間質空間内でス シズメ現象を発生し，収縮的には拈互同志のス レアイによる内部抵抗の増加のためのエネルギ 一のロスとなって, さらに心筋肥大促進因子と して働き, 細胞間に全く物理的に結合織線維の
増加を招き，ひいては心筋コンプライアンスの 低下を発生して拡張終期圧の上昇など一種の拘 束性 (Restricitive) 機能障害を持つにいたるこ とが予想される。また正常の 4 倍，8倍という 著明な重量増加は, 狭窄をもたない正常の冠状 動脈といえどもその余力を超えて, 単位心筋体 積当りの $\mathrm{O}_{2}$ 供給は相対的に低下し, 虚血性病 変を合併するにいたる. 冠不全のための 2 次的 心筋脱落之置換性線維症は, 前述の拡張型と同 じ理由で左心室後壁につよく表現され，その部 分は収縮要素が減少するため図 $2 \mathrm{D}$ のように余 分に引きのばされてうすくなる．肥大群でも進 行性の内腔拡張の増加に肥大が扔いつけなくな ると収縮能低下によるらっ血型心筋疾患の病像 を呈することになる。しかし相対的虚血の存在 から予想されるようにうっ血型のフルコースを 完走する前に不整脈死を含めて急死に終る例も かなり存在することもらなづける病理像とい光 る.この型の成因上心筋肥大の引き金となり, それを非可逆的状態に固定するに十分な心搪張 と，拡張に対する反応として肥大する能力を心 筋が保持しつづける条件が要求されるわけであ る.

心筋の脱落後の線維症であれ，心筋の性状に 関係なく積極的に 間質線維が増加する 型であ れ, 線維症が心筋内に発生すると, 一般論とし ての拡張・肥大の法則はあてはまらなくなる. コラゲン線維は引きのばされに対して強力な抵 抗力を発揮するため, びまん性心筋線維症は心 室内腔の拡張に対して抑制的に働き，心筋収縮 に対して内部抵抗を増し拘束性病像を正面にだ してくる. 収縮時の抵抗増加は, 心筋細胞肥大 促進に働くので, 線維症のワク内で限度一杯の 肥大も合併することになる。著者はこのような 肥大は肥大型に入れずにあくまでも心筋線維症 の 2 次的産物とみなして線維症型とみなしてい る。したがって線維症を主徵とする特発性心筋 疾患と拡張 -肥大群に合併する 2 次的線維症の 鑑別は, 前述の 2 次的線維症の好発部位では説 明できない線維症であることを証明すればよ い. 図 $2 \mathrm{E}$ 例は肥大のつよい巨大心であるが, 線維症は不規則, かつびまん性で心室中隔前半 


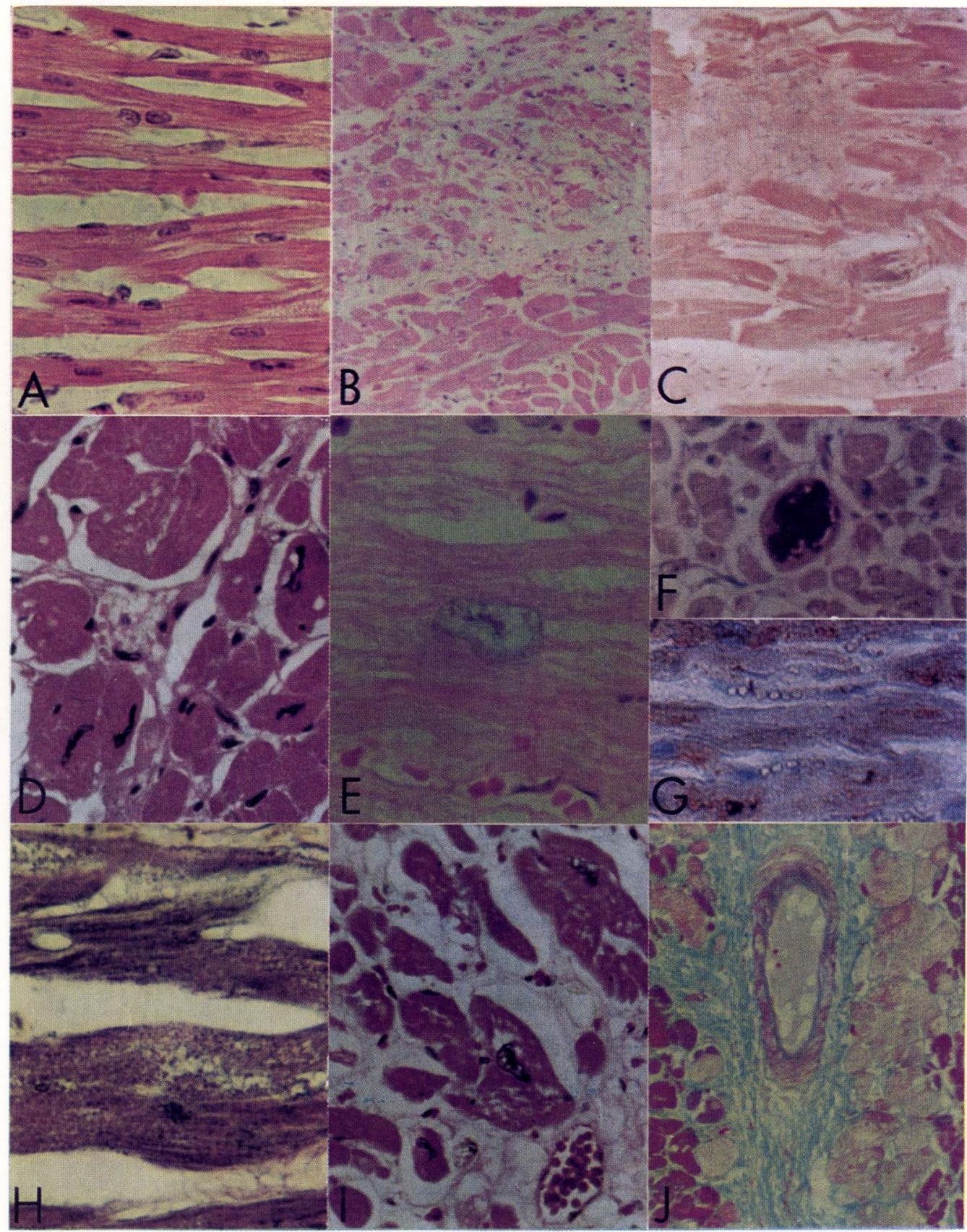

A：正常心筋， $200 \times, H E$ 染色. B：変性型特発性心筋疾患, $100 \times, \mathrm{HE}$ 染色. C：変性型特発性心筋 疾患, $200 \times, \mathrm{HE}$ 染色. D：肥大型特発性心筋疾患， $200 \times, \mathrm{HE}$ 染色. $\mathrm{E} \sim \mathrm{J}$ ：混合型特発性心肥大 症, E: $400 \times$, HE 染色. F： $200 \times$, HE 染色. G： $200 \times$, Sudan III 染色. H： $400 \times$, 鉄へマトキ シリン染色. I: $200 \times$, HE 染色. J: $200 \times$, Azan 染色.

図 3 変性型・肥大型・混合型特発性心筋疾患の組織学的所見 

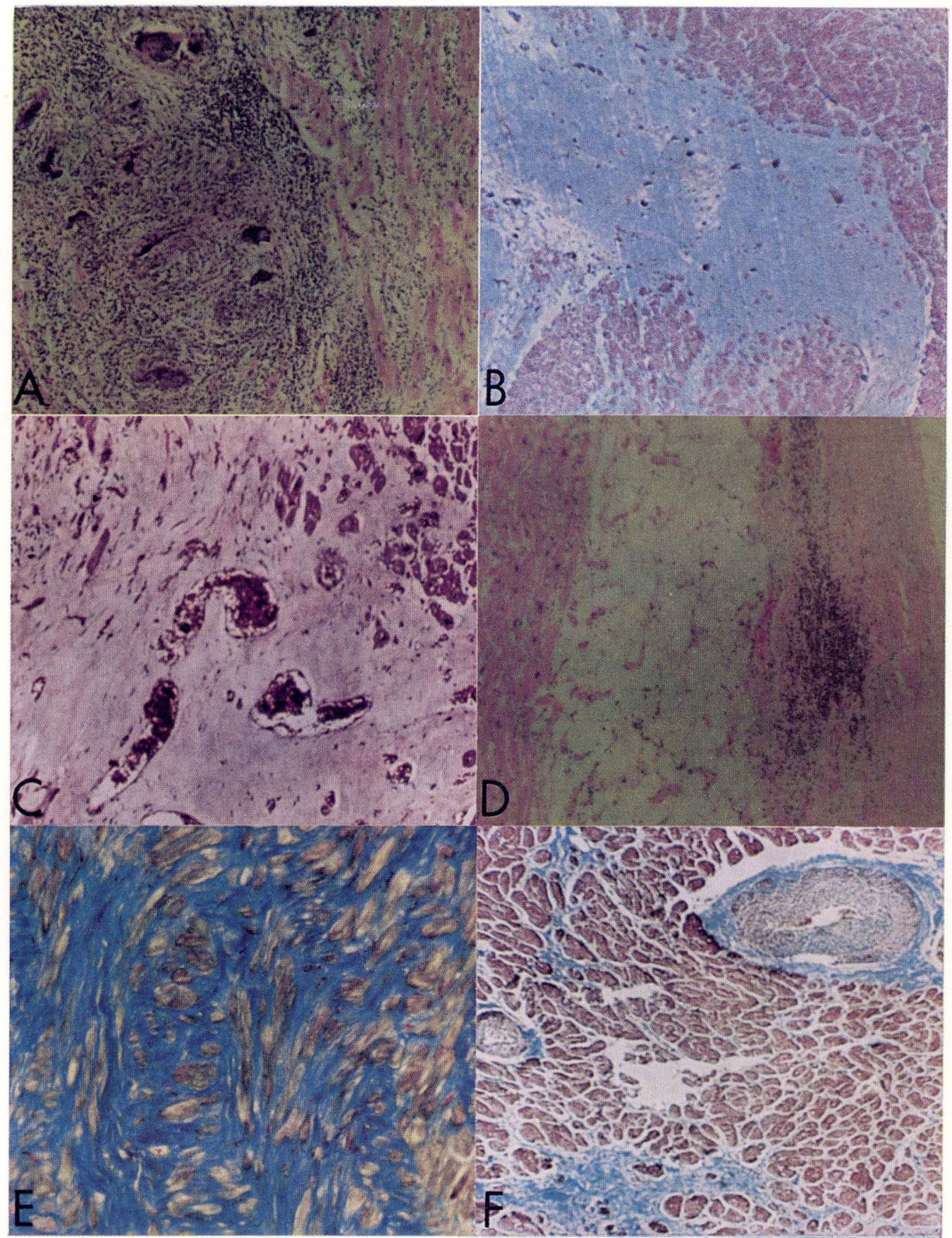

A：巨細胞性心筋炎, $40 \times$, HE 染色. B：心筋炎後心肥大. $40 \times$, Azan 染色. C：心筋炎後心肥大, $40 \times, \mathrm{HE}$ 染色。 D：心筋炎後心肥大に合併した心外膜炎, $40 \times, \mathrm{HE}$ 染色. E：びまん性間質心筋線 維症, $40 \times$, Azan 染色. F：小血管硬化に伴 5 心觔線維症, $40 \times$, Azan 染色.

図 4 線維症型特発性心筋疾患者の組織学的所見 
にむしろつよく，心外膜・心筋炎治癒後の線維 症の遺残が心内腔の拡大とともに肥大の成因と なったと考光れば，図 $1 \mathrm{E}$ のように心筋内張力 はたと无正常に近くても，内部抵抗の増大がつ よく肥大を促進したと理解できる.

以上の 3 群に大別される特発性心筋疾患も長 い経過をとると当初はどの型であれ最終的には 心筋変性・肥大・線維症が入りまじる混合型心肥 大症となりらるわけである。図 $3 \mathrm{E} \sim \mathrm{J}$ は一応 混合型とよべる各成分の混在する例の心筋であ る。 $\mathrm{E}$ 図は核の巨大化を伴らつよい心筋細胞の 肥大が高度の心内腔拡張に誘発された所見であ り， $\mathrm{H}$ 図のごとく部分的に筋原線維が顆粒状に 変性している像は周辺に虚血時によく観察され る小空胞の連鎖状出現 (Kämmerchenkettenbildung）をみることより肥大による相対的アノキ シアを病因と考えても矛盾はない26)。図 $\mathrm{F}$ に示 すムコイド変性 27 は，たしかに特発性心筋疾患 飞多くみられ，内因性心筋細胞代謝失調の表現 とみることは可能であるが，肝疾患などに伴う Myokardose 変化 ${ }^{28229)}$ や老㱓者心筋でもよくみ られるので特発性心筋疾患特異的といらわけで はない，G図の小脂肪滴の細胞内出現も慢性虚 血時の特長である，I図の心筋細胞の太さの著 しいバラッキはD図のような肥大を括こしたの らに拡張による引きのばされをらけて, 細胞周 囲の網状の線維症とともに 2 次的に発生したも のであろう。この細胞原形質内に多数存在する 小空胞の一部は肥大にともなって増加・巨大化 したミトコンドリアの存在部位 (Mitochondrien-sichtbar-werden）を示し相対的虚血でも説明 できる。 J 図の正常な心筋内小血管周囲の線維 症およびその周囲の膨化した細胞群・凝固壊死 に陥った細胞群も拡張・肥大による心筋構築の 変化と, 未期の心不全で説明されるものである. したがって混合型心筋疾患といっても以上述べ たルールを適用して，もっとも優位を占める病 理所見が決定でき，それが病因により近いもの と仮定して矛盾がない場合は, 変性型・肥大型 - 線維症型のどれかの末期像として, 多くの例 は著者の特発性心筋疾患 3 型のどれかに分類で きるはずである。したがって混合性心肥大の名
称を残してあるのは, 以上述べたよらに特発性 心筋疾患の病理所見が非特異的な変化を多く含 んでいるため, 組織学的所見がそのまま病因に 直結せず，初期の病変がさまざまの修飾をうけ るのは不可避であるので, 診断の難しい症例は 強いて変性・肥大・線維症型にまで分類せずに, 病因分析が進むまではそのまま残して拉こうと いら考学の人に利用してもららためである.

\section{II. 特発性心筋疾患にみられる特異的病变}

\section{1. 拡張の原因とみなしうる心筋変性}

変性型心筋疾患にみられる純拡張は, 心筋細 胞の機能異常が心拡大によってのみ生存に可能 な心拍出量を維持できる状態にまで，悪化して 生じるので第 1 要因としてアクチン・ミオシン 系またはその活動を維持するための酵素系に障 害が発生していることが予想される。拡張に対 して正常反応としての肥大を伴わないという第 2 要因は, 比較的臨床経過の短い例では第 1 要 因と同じであると予想できることもある.

図 3 B 例は, 経過 3 週程度であるため, この心 筋脱落巣は病初から継続進展した心筋病とみな しうるので，このような変性一脱落が既知の病 変のらち，なんと類似性があるかを検討するこ とで病因に肉薄でさる，全体像としては一番近 い病変は進行性筋ジストロフィー症の心筋にみ られる ${ }^{30)}$. 心筋原形質の均一染色性所見は横紋 の不明化を招き蛋白質の変性かまたは外来性蛋 白質の進入している事態が推定される．白血球 性細胞浸潤が全くみられないこと，間質の反応 もかなり鈍いことは通常の炎症と異なる所見で あり,これを炎症とみなすには従来の実験的・人 体病理学的観察と次元をことにした slow viral infection でももってこないことには同意できな いことになる ${ }^{31)}$ 。神経系ではクールー病などで 変性所見が前面にでるウイルス感染も証明され ているが，心筋では未だかような形の感染は知 られていない。図 $3 \mathrm{C}$ 例の間質の線維症は同 B 例の変化が長時間経過して発生したものとみな して驚く程よく一致して拈り，この場合にはか っての変性因子が長く弱く働いて肥大を妨げた とみなして差支えなからう。 
その汪か類似心筋病変をもつものとしてはア ルコール心筋症 32 , 一モクロマトージスなどが あげられる。からな見方からは，この範瞦に 入る心筋疾患は, 心筋の代謝失調につながる異 常で光学顕徴鏡的に明らかな心筋細胞の変性を 生じさせるものが第 1 病因としてもっとも抵抗 なく考觉られる。

\section{2. 肥大にみられる特異性}

肥大を扣こさせる先行病变が線維症や認めら る程の心筋の欠落など続発性非特異性肥大を生 じさせるのに足る物的証拠をのこしていない場 合が肥大型心筋疾患である。したがって心筋の 脱落にまで進展しなかった可逆的心筋变性や心 筋炎が拡張の第 1 因子として働き, 拡張がある 時間続いたのちに初発病変は痕跡をとどめずに 治癒し，あとに自発的に進行する肥大のみ残っ たというコースが一つ考えうる，心筋炎が実質 にも間質にも痕跡を残さず治癒することはリウ マチ性心疾患の心筋病変 ${ }^{33)}$ からみても考它にく く, 実際上は 1 . の変性型の治癒型と考兄る方 がはるかに現実的である，肥大した心朌細胞質 内に蛋白変性物質とみられる微細線維性または 管状構造物をみとめる症例 ${ }^{34)}$ のることは肥大 の第 1 病因として細胞内物質代謝失調を推定で きるものも含をれていることを示㖫する。

もら一つの問題は求心性非対称性肥大として 発症した肥大性閉塞性心筋疾患が非代償状態と なって内腔拡張を生じ, 非閉塞性拡張性肥大型 心筋疾患となる可能性にある。 ある種の動物に 家族性に発生しうる心筋疾患ではこの移行の可 能性があるといわれている ${ }^{35)}$ ，しかし著者のヒ 卜剖検例の検討では, 図 $2 \mathrm{C} ・ \mathrm{E}$ のようにみか け上類似性をるつ例もあるが，よくみると図C 例では中隔心筋の構築は極立った異常を呈して おり，雨者の移行型の存在は確認できず，ない かまたはごく稀であると考学られる。

\section{3. 先行病変としての線維症の特異性}

第 1 病因として心筋に 非可逆性病変が発生 し, 治痛後に線維症をのこすと心筋内部抵抗を たかめることにより心肥大を促進する可能性が 大きい，線維症が肥大の引き金となったと推定 される症例で, 果して線維症の前にいかなる心
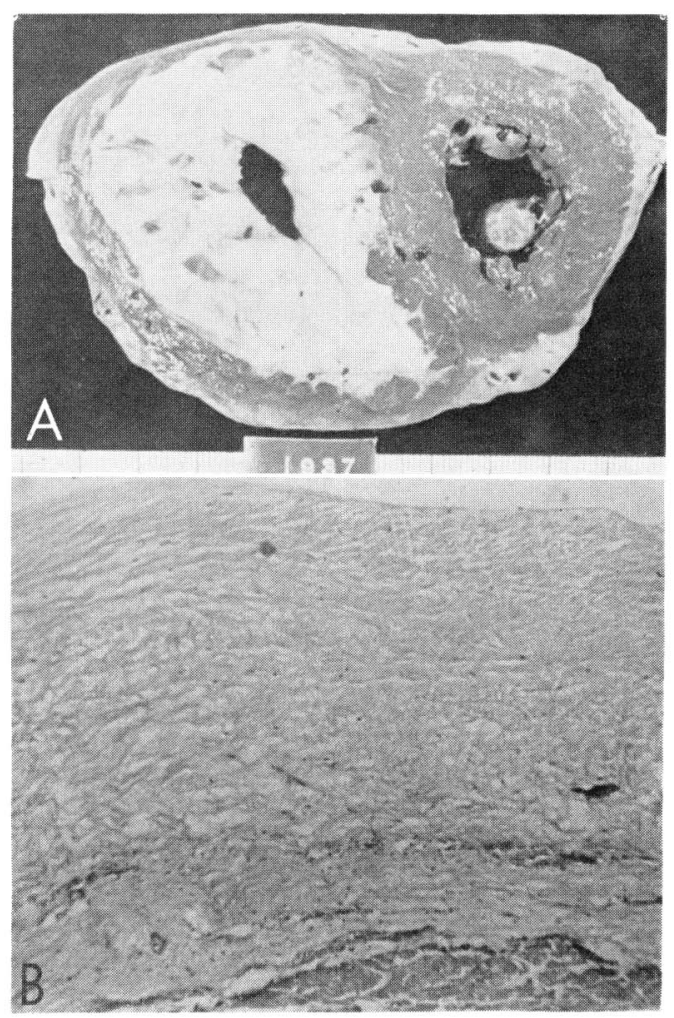

A：心臟横断面。右心室内面の線維症による狭 小化

B：心内膜の厚い硝子様線維肥厚. $40 \times$, HE染 色

図 5 心内膜心管線䧽症 (Davies)

筋病変が先行したか診断できるであろらか?

図 4 A に示すよらな心筋炎とくに血管周囲に病 変がつよい間質性心筋炎後の線維症は図 $4 \mathrm{~B}$ K 示すように心等内に広汎かつ不規則に分布し， 図 $4 \mathrm{C}$ のように新生小血管に富むのが普通の所 見である。しばしば図 4 Dに示すごとき心外膜 炎を合併し, 臨床的に心外膜 - 心筋炎の形をと ることが多いウイルス性とくに Coxsackie B 型 心筋炎 ${ }^{36)}$ 之対応しているよ5である。この際, 急性・西急性・慢性をとわず心筋炎の状態では 心昖張はみられても肥大の合併は少なく, 心筋 炎が一応瘷痕治瘾をとげたあとで生き残り心筋 が肥大して心重量の増加があらわれることに注 意したい. したがって慢性心筋炎と心筋炎後心 肥大症は決して同義ではない，心筋炎後の症痕 が極端に大きなひろがりをもつときは生き残り 心筋の肥大をもってしても心不全が予防でき 
ず，心重量の目立つ増加なしに死亡することも ありらるが，一般には心筋炎後心肥大は図 $2 \mathrm{E}$ のように高度となり，線維症の存在による壁内 抵抗の増加は, 心内腔の過度の拡張よりも, む しろ中等度の拡張につょい肥大を合併する肥大 優位型を発生することがある。この際，心室中 隔頂上部に副束をもつ WPW 症候群をたまた ま合併すると, 中隔の早期興奮が心筋肥大をと

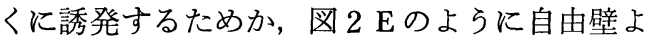
り中隔の厚い特異な心肥大を合併する15).

図 $4 \mathrm{E}$ 例は，以上の型と趣を異にする心筋細 胞の周囲をびをん性かつ密にコラゲン線維がと りかこむびまん性間質性線維症型である ${ }^{37) 38) . ~}$ 伝導系をも含めて生理的にコラゲンの多いとこ ろで線維症も密となることから，むしろ膠原病 の強皮症・皮䖉筇炎などと類似性がある。

図 $4 \mathrm{~F}$ 例は, 心筋内小動脈の原因不明の中膜肥 厚による虚血性心筋線維症が広汎にみられた例 で家族的に同じ形の心疾患が発生している ${ }^{39)}$.

以上，組織学的には形に相違はあるが，広沉 な線維症は心室の拡張制限・コンプライアンス の低下を招き, 内圧の上昇や高度の拡張がなく ても拘束性病像に対応して心筋肥大を合併する にいたることは確実な事実である。この際 2 次 的肥大はもとの線維症の型・程度により比較的 軽いものから高度のものまでバラッキを示すこ とも当然といえる。

この項でとりあつかった病理像は，一つ一つ をとりあげればなにも特異的ではない，しかし それらがまとまって一つの組み合せをつくると き，他の既知の病因による像と相違をもつこ と，また病因不明の心筋疾患の中でも組合せの ニュアンスに差がでることは事実である.

\section{III. 類縁疾患の病理}

特発性心筋疾患の類縁疾患とは, 同じく病因 不明であるが病理学的に心筋以外たと壳ば心内 膜に著明な病変をもつもの, 病原菌は不明でも 明瞭な炎症所見をもつもの，心筋疾患であって も極立った特長により他とはっきり区別できる ものなどが含まれる。

すでに前項で述べたように肥大性閉塞性心筋
疾患は，非対称性に心室中隔肥大がつよい点で 著者のいら肥大型，心筋炎後心肥大症のどちら とも，画然と区別されるので別ワクとした．臨 床的には同一家系内に閉塞性所見をもつもの， 非閉塞性のものが出現することなどより両者間 には明確な区別はないとの議論もあるが40)，心 室中隔の軽度の形成異常が時日の経過とともに 肥大として顕在化すると考劣れば，もとの形成 異常の程度が閉塞性に将来発展しらるだけつよ いかどらかで型わ忷がきまるので，完成像で形 態学的に閉塞性・非閉塞性が明確に区別される 以上両者は別物とみなして少しも差支えはな い。それは同一家系内に高血圧者と正常血圧者 が混在するのとさして変りがないといえよう。

一度肥大した中隔は，たと光臨床経過中に心不 全などにより閉塞所見が軽快した場合でも形態 学的には明らかに肥大像を維持するので剖検所 見で拡張性肥大型とまぎらわしくなることはあ り得ない。

心筋炎とくに間質性心筋炎は, 組織学的に線 維性治癒を営んだのちに心筋炎後心肥大症とな って特発性心筋疾患の 1 群を生じるが，小部分 にでも炎症所見が残存している場合は心筋炎の 範疇に入れるべきで, 両者の移行期は臨床的に はあり得ても病理学的にははっきり区別するべ きである.すなわち慢性心筋炎は, 特発性心筋疾 患ではなく，あくまで炎症が消退したのちの線 維症の存在が原因となって肥大・拡張を生じた 場合のみ特発性心筋疾患と考えるべきである。

心内膜の広汎かつつよい線維性または線維弾 力線維性肥厚を，心筋病変に合併した場合も同 様で，まず炎症所見が残存する場合は壁心内膜 （心筋）炎であり，炎症がみられない場合が心 内膜心筋線維症 ${ }^{41) 42)}$ ・ 心内膜心筋硬化症 ${ }^{43) 44)}$ で ある。アフリカに多い Davies 病（心内膜心筋 線維症）では図 $5 \mathrm{~A}$ のように心室の内面を線維 症が埋め塞いで内腔狭小性 (Obliterative) 変化 を発生することがある，肥厚した心内膜は，図 5 B のように弾力線維に乏しく硝子様外観をと ることもある ${ }^{45)}$.

心内膜炎または心内膜心筋炎には血中好酸球 増加をみる Löffler 心内膜炎 ${ }^{46)}$ があるが， 類似 
の変化が好酸球性または単球性白血病でもみら れることは興味深い47). 好酸球増加がなくて同 じような心内膜炎を発生することも知られてお り，その中のあるものは心内膜線維弾性症にま で進展して心内膜心筋硬化症の範疇に入る心疾 患となる ${ }^{43}$. 一一方, 特発性心筋疾患の一部は、巨 大な心内膜血栓形成をもち，その器質化による 心内膜肥厚を続発して同様に心内膜心筋硬化症 にまで進みうる44). いずれにしても心内膜病変 の共存が心筋病変の分布を心内膜よりに近づけ る効果は毎常みられている5 ${ }^{548}$. この群も心室 の拡張制限に加えて, 線維組織により内部抵抗 が増加するため収縮不全が加わることになる。 この群では心内膜血栓器質化に伴ら細胞浸潤と 真の壁心内膜炎との 鑑別は必ずしも容易でな く，心筋炎と特発性心筋疾患のような明確な区 別は難しいことがある。

原発性胎児性心内膜線維弾性症は, 3 歳まで にほとんどが死亡し, 心内膜下血管網の荒㾱を みること心内膜 - 心内膜下心筋の病変が心笳層 と明確に区画されていることなどから胎児性心 内膜心筋炎が引き金となっている可能性があ $る^{49)}$.

\section{おわりに}

特発性心筋疾患 - 類緑疾患の病理学的型分け は, 第 1 の病因に加兄て種々の 2 次的変化が第 2 病因として加わって病像を修飾するために, 終末像をいかに精細にわけてもそれだけでは原 因別分類にならない，また，たと元一病因でも 強く働く場合, 弱く働く場合, 永く働く場合, 短く働く場合で生体の反応は変化してくるはず である，そこで単に似ているものを並べるだけ でなく, その病変の中から 1 次的な病因の働い たあとを注意深く探りだして 2 次的病変の進展 のあとを差し引いてできるだけ病因の近くまで 肉薄する態度が, 臨床的分類といつも密接して 考えること50)とあいまって重要であると著者は 考えている.

\section{文献}

1) 岡田了三: 特発性心疾患 Idiopathic myocar- diopathy 扤よび類縁疾患 Allied Cardiac Disease の病理学的考察. 臨床科学, $5 ; 1625$, 1969.

2) Feifar, Z.: Cardiomyopathies-An International Problem. Cardiologia, 52; 9, 1968.

3) Okada, R.: A Morphological Classification of the Idiopathic Myocardiopathy and Allied Cardiac Diseases. Jap. Circulation J., 35; 755, 1971.

4) 岡田了三: 特発性心筋疾患の病理像. 綜 合 臨 牀, 22；234， 1973.

5）岡田了三：特発性心筋疾患および類縁疾患の病 因的考察. 代謝, 7；834，1970.

6) 岡田了三: 特発性心筋症の病理的アプローチ. 新菜と治療, 144；23，1970.

7) 岡田了三: 特発性心肥大症の病理. 呼吸々循 環, 9; 313, 1961.

8) Okada, R., Glagov, S. and Lev. M.: Different Effects of Increased Volume and Increased Pressure on Endocardial Structure in Hearts with Atrial Septal Defect. Amer. Heart J., 75; 474, 1968.

9) Burton, A.C.: The Importance of the Shape and Size of the Heart. Amer. Heart J., 54; 801, 1957.

10) Linzbach, A.J.: Die pathologische Anatomie der Heizinsuffizienz. Handbuch d. inner. Medizin. 4t Aufl. s. 706, Springer-Verlag. Berlin, Göttingen, Heidelberg, 1960.

11）岡田了三：心蔵の形態学 (11), メデカルェレ クトロタイムス, 12(3)；27, 1970.

12) Ohkawa, S., Sugiura, M., Iizuka, T., Shimada, H. and Okada, R.: Three Cases of Idiopathic Cardiomegaly in the Aged. Jap. Heart J. 12；305, 1971.

13）木村 登, 戸嶋裕德, 深水孟, 中浦靖久: Idiopathic Hypertrophic Subaortic Stenosis (IHSS). 臨床科学, 5; 1565, 1969.

14）並木恒夫：国立仙台病院例。個人的好意に上る 提供.

15）水谷孝昭, 望月 茂, 角水圭一, 桐山利昭, 和 田勝, 影山邦子, 山下光洋, 松本繁之助: 長期 にわたり大量の心外膜液貯留を伴った特発性心 筋症の 1 剖検例. 心臟, 4; 338, 1972.

16）上田英雄, 神坂和明, 小池繁夫, 大野京子, 大 森亮雅：肺硬塞を主徵した出産後特発性心疾患 の 1 剖検例. 日内会誌, 58；417, 1969.

17）杉浦昌也, 岡田了三, 飯塚 啓, 久保富美子, 大川真一郎, 沜田裕之：老年者に扣いて互に異 
なる病像を呈した特発性心肥大の 3 例。日内会 誌， $\mathbf{5 7} ; 1132,1968$.

18）河村慧四郎，James，T.N.：心筋細胞の結合，日 本臨牀，31；12，1973.

19) Burton, A.C.: Relation of Structure to Function of the Tissues of the Wall of Blood Vessels. Physiol. Rev., 34; 619, 1954.

20）真島英信：生理的概念としての Vmax. 日本臨 牀, 30；2030，1973.

21）岡田了三：心不全の病理。最新医学, 25；14, 1970.

22) Goodwin, J.F. and Oakley, C.M.: The Cardiomyopathies. Brit. Heart J., 34; 545, 1972.

23）上杉昌秀, 西条 敬, 岡田了三, 北村和夫：弁 膜症による心不全の臨床像における問題点。臨 床成人病, 3；645, 1973.

24）藤井 潤, 矢崎義雄：心肥大に関する最近の進 歩. 臨床科学, 5；1616, 1969.

25) Messen, H.: Structural Bases of Myocardial Hypertrophy. Brit. Heart. J., 33 Suppl; 94, 1971.

26）掛札 堅：心筋障害心電図の病理形態学的基礎 一心筋硬塞並びに冠不全症の異常心電図波形々 病理組織学的所見との対比的研究一. 日病会誌, 47; 771, 1958.

27) Mamiya, N.: Contributions to the Studies on glycoprotein Degeneration of Heart Muscle. Med. J. Shinshu Univ., 7; 1962.

28）岡田了三, 所沢 剛, 斉藤 守: 心筋変性と心 電図との相関一特に盰性ミオカルドーゼを中心 として。日病会誌, $50 ； 212,1961$.

29）上田英雄, 岡田了三：原因不明の非血管性非弁 膜性心疾患.日本臨床, 21；180，1963.

30) Ueda, K., Okada, R., Matsuo, H., Harumi, K., Yasuda, H., Tsuyuki, H., and Ueda, H.: Myocardiol Mvolvement in Benign Duchenne Type of Progressive Muscular Dystrophy. Jap. Heart J. 11；26, 1970.

31）河合忠一, 北浦 泰, 塚田裕久, 堀健次郎, 鷹 津 正：特発性心筋症 (idiopathic cardiomyopathy). 心臓, 3; 848, 1971.

32) Evans, W.: Alcoholic Myocardiopathy. Prog. Cardiovas. Dis., 10; 151, 1964.

33) 岡田了三, 羽里信種: リウマチ性心臓病の臨床 病理学的研究一特にその結合織病変の形態学的 成因と酸性ムコ多糖類の組織化学的分析につい て一.リウマチ, 12; 13，1972.

34) Takatsu, T., Kawai, C., Tsutsumi, J., and Inoue, K.: A case of Idiopathic Myocardio- pathy with Deposits of a Peculiar Substance in the Myocardium; Diagnosis by Endomyocerdial Biopsy. Amer. Heart. J., 76; 93, 1968.

35）岡田了三：特発性心筋疾患. 日本臨牀, $\mathbf{3 0} ; 72$, 1972.

36) Gardiner, A.J.S., and Short, D.: Four Faces of Acute Myoepicarditis. Brit. Heart J., 35; 433, 1973.

37）八过行信, 中島克彦, 大川真一郎, 高皇 豊, 春見建一, 上田英雄, 長谷川嗣夫, 三井利夫, 堀原一, 三枝正裕：洞房・房室・心室内伝導 障害を伴った原発性心筋疾患の1剖検例. 日循 誌, 31；1271, 1967.

38）岡田了三：心電図診断の実例と解説. 心笳疾 患. 臨牀と研究, 48；1941，1971.

39) Okada, R., Harumi, K., Nomura, M. and Murao, J.: A Case of Coronary Sclerosis in Small Arteries Associated with Diffuse Myocardial Fibrosis. Jap. Heart J., 1; 348, 1960.

40) Oakley, C.: Veutricular Hypertrophy in Cardiomyopathy. Brit. Heart J., 33 Suppl; 179, 1971.

41) Nakajima, K., Okada, R., Ueda, H.: A case Replort of Endomyocardial Fibrosis. Jap. Heart J., 2；265， 1961.

42）村上精次, 塩川優一, 村上正中, 山内英士, 本 康 勝, 萩谷 暠, 小林陽太郎, 鉿木秀雄, 渡 辺茂: Endocardial Fibroelastosis $の 1$ 例. 日 循誌, 31；361，1967.

43）岡田了三, 横山栄二, 野村武夫 : びまん性心内 膜層硬化症(Diffuse Endomyocardial Sclerosis) の 1 症例について。呼と循, 6 ; 579, 1958.

44) 上田英雄, 村尾 覚, 安田寿一, 片山宗一, 岡 田了三：心内膜筋層硬化症 (Endomyocardial Sclerosis) の 2 症例一その典型例と不全例。日 循誌, 27；765，1963.

45) Davies, J.N.P., and Ball, J.D.: The Pathology of Endomyocardial Fibrosis in Uganda. Brit. Heart. J., 17; 337, 1955.

46) Löffler, W.: Endocarditis parietalis fibroplastica mit Bluteosinophilie. Schweiz. med. Wochenschr., 66; 817, 1936.

47) 岡田了三：線維形成性壁心内膜炎(Endocarditis parietalis fibroplastica）とその類似疾患. 内科, 7; 463, 1961.

48）岡田了三：成人にみられる原因不明の心内膜肥 厚の形態学的分析. 日循誌, $\mathbf{3 4} ; 125,1970$.

49）岡田了三, Lev. M.：いわゆる胎児性心内膜線 維弾性症の形態学的検討. 日循誌, 34; 125, 1970,

50) Grosse-Brockhoff, F.: Zur Klassifizierung, Ätiologie und Pathogenese der Myokardiopathien. Deut. med. Wochschr., 96; 659,1971, 